\title{
CHANGING ENVIRONMENTS AND HUMAN SETTLEMENT DURING MID- HOLOCENE IN RIO DE MOINHOS BEACH (ESPOSENDE, NORTHERN PORTUGAL)
}

\author{
HELENA GRANJA $^{(1)}$, SÉRGIO MONTEIRO-RODRIGUES ${ }^{(2)}$ \& RANDI DANIELSEN ${ }^{(3)}$
}

\begin{abstract}
:
This work results from a combination of sedimentological, palaeocological and archaeological data, made available due to special meteo-marine conditions that removed sand from the beach of Rio de Moinhos, exhuming older sedimentary deposits and bringing into evidence a huge amount of archaeological remains - Prehistoric and Roman (the latter not considered here).

In this paper the relationship between the palaeoenvironments and the contemporary human evidence is analysed. The time interval considered in this study goes from $5590 \pm 80 \mathrm{yr}$ BP (4614-4319 cal BC $2 \sigma)$ to $3550 \pm 30 \mathrm{yr}$ BP (2007-1772 cal $\mathrm{BC} 2 \sigma$ ) and encompasses a succession of environments comprising an Alnus forest, a wetland, a brackish lagoon and a fresh water lake, showing a progressively finer and more organic sequence, and higher infilling rates. Initially, in the wetland phase, there are no certain traces of human activity in the pollen content, but from around $4860 \pm 30 \mathrm{yr} \mathrm{BP}$ (3703-3539 cal BC $2 \sigma$ ) cereal cultivation and agriculture are detected. Later on indications of grazing also appear. However, human presence is well documented by a lithic assemblage dated from the interval between $5590 \pm 80$ y BP (4614-4319 cal BC $2 \sigma)$ and $4680 \pm 30 \mathrm{yr}$ BP $(3622-3370 \mathrm{cal} \mathrm{BC} 2 \sigma)$. Another lithic industry predates $5590 \pm 80 \mathrm{yr}$ BP being therefore prior to the Alnus forest. Apparently, it documents the earliest evidence of human presence at the site.

Keywords: Mid-Holocene; lagoon environment; Palynology; lithic assemblages; Rio de Moinhos beach.
\end{abstract}

Resumo:

\begin{abstract}
Mudanças ambientais e ocupação humana durante o Holocénico médio na Praia de Rio de Moinhos (Esposende, Norte de Portugal)

Este texto resulta da combinação de dados sedimentológicos, paleoecológicos e arqueológicos obtidos na sequência de condições meteorológicas e marinhas particulares, que provocaram a remoção de areia da praia de Rio de Moinhos, expondo depósitos sedimentares antigos e inúmeros vestígios arqueológicos - Pré-históricos e Romanos (estes últimos não considerados neste trabalho). Nele são analisadas as relações entre os paleoambientes e as evidências da presença humana no local.

O intervalo temporal considerado está balizado entre $5590 \pm 80$ yr BP (4614-4319 cal BC $2 \sigma)$ e $3550 \pm 30$ yr BP (20071772 cal BC $2 \sigma$ ), período durante o qual ocorreu uma sucessão de ambientes que compreendem uma floresta de Alnus, uma zona húmida pantanosa, uma lagoa de água salobra e um lago de água doce, revelando uma sequência sedimentar progressivamente mais fina e orgânica, com taxas de acreção cada vez mais elevadas. Inicialmente, durante a fase pantanosa, o registo polínico não revela vestígios claros de actividade humana; a partir de $4860 \pm 30$ yr BP (3703-3539 cal $\mathrm{BC} 2 \sigma$ ) a agricultura, nomeadamente a cerealífera, passa a estar bem documentada. Um pouco mais tarde aparecem igualmente indicadores da prática do pastoreio.

Todavia, a presença humana no local está confirmada por uma indústria lítica datada do intervalo entre $5590 \pm 80 \mathrm{yr} \mathrm{BP}$ (4614-4319 cal BC $2 \sigma)$ e $4680 \pm 30$ yr BP (3622-3370 cal BC $2 \sigma)$. Um segundo conjunto lítico é anterior a $5590 \pm 80$ yr BP, ou seja, anterior ao desenvolvimento da floresta de Alnus. Ao que tudo indica, este conjunto testemunha os vestígios humanos mais antigos conhecidos neste sítio arqueológico.
\end{abstract}

Palavras-chave: Holocénico médio; ambiente lagunar; Palinologia; indústrias líticas; Praia de Rio de Moinhos.

Received: 21 March, 2016; Accepted: 30 May, 2016

\section{INTRODUCTION}

In 2005, following adverse meteorological conditions, the beach of Rio de Moinhos, in Esposende (Fig. 1), lost a lot of sand, exposing, for the first time, hidden pieces of the history of this coast. It was possible to observe not only exhumed sedimentary deposits overlying the bedrock but also tree stumps in life position, several wood artefacts and a huge quantity of Roman pottery.

The first notice concerning this case study was presented in Braga in 2010 (GRANJA \& MoRAIS 2010) and in Belgium in 2012 (GRANJA et al.
2012). Later on, some preliminary results from multidisciplinary approaches were published in MORAIS et al. (2013), MONTEIRO-RODRIGUES et al. (2013), OLIVEIRA et al. (2015) and GRANJA \& DANIELSEN (2015).

Meanwhile, sand re-covered the deposits and the findings but at the end of December 2012, during an occasional trip to the beach, it was possible to observe that a dark deposit outcropped again at low tide. By the beginning of 2013, the extension of the outcropping deposit had doubled.

\footnotetext{
${ }^{(1)}$ CIIMAR - Interdisciplinary Centre of Marine and Environmental Research. University of Porto, Rua dos Bragas 289, P 4050-123 Porto, Portugal.

${ }^{(2)}$ University of Porto, Faculty of Arts. CITCEM - Transdisciplinary "Culture, Space and Memory" Research Centre. Via Panorâmica s/n, P 4150-564, Porto, Portugal .

${ }^{(3)}$ Herdla Museum, Museum Vest, 5315 Herdla, Norway.
} 


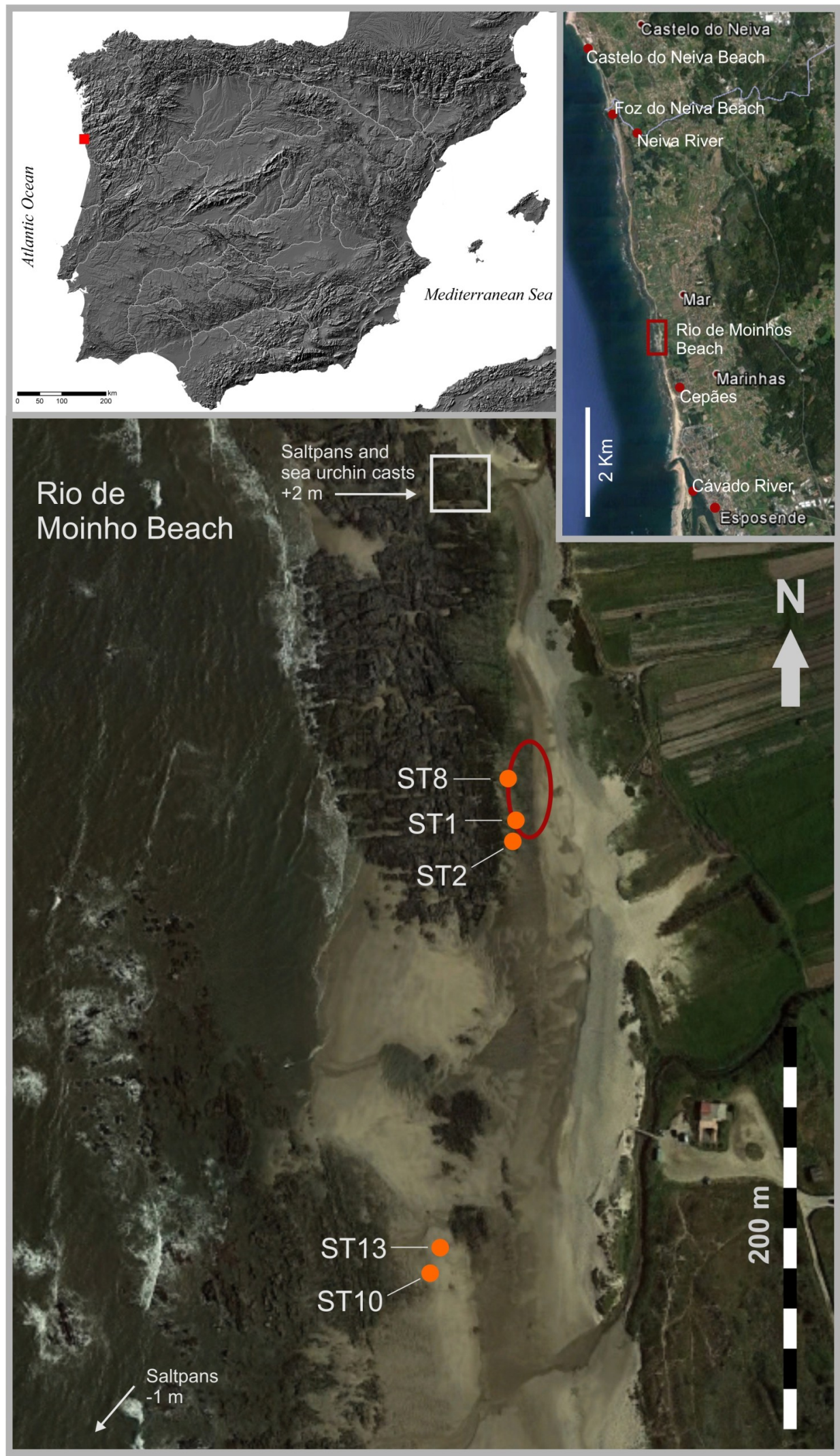

Fig. 1. Rio de Moinhos beach location. Position of the ST cores and lithic artefacts (red oval: area with the highest concentration of lithics) (Ortophoto extracted from Google Earth 7.1.5.1557).

Fig. 1. Localização da praia de Rio de Moinhos. Localização dos cores ST e dos artefactos líticos (oval vermelha: área com maior concentração de artefactos líticos) (Ortofoto extraída do programa Google Earth 7.1.5.1557). 
At the same time (between December 2012 and the beginning of January 2013) a prehistoric macrolithic assemblage, made of quartzite pebbles, was identified at the surface of the dark deposit outcrop. This finding was considered quite relevant because it was connected to an unprecedented archaeological context, apparently very well preserved as the artefacts seemed to be found in primary position. Indeed, both the lithic artefacts and the thermoclasts did not present any sign of rolling; some of them could be refitted (the distance between the refitting elements did not exceed $2 \mathrm{~m}$ ); and there was an important number of very small flakes among the assemblage (MONTEIRO-RODRIGUES 2013).

In January 2013, another set of artefacts - these strongly rolled - was identified both at the surface of the outcrop as well as at the base, more precisely in a marine conglomerate that underlay the dark sedimentary deposit (MONTEIRO-RODRIGUES 2013).

These two assemblages seem to document distinct moments of Human presence at the site, temporally far apart.

Through the study of exhumed sediments and correlative lithic artefacts found at the beach of Rio de Moinhos, this paper intends to be a contribution to the understanding of how the interactions between people and the surrounding environment occurred during a period of intense changes, between c. 7000 and 3000 yr BP (c. 5000 and 2000 BC).

\section{GEOLOGICAL BACKGROUND}

The beach of Rio de Moinhos, north of Esposende (Fig. 1), between the Neiva and Cávado rivers, is located over a rocky platform (with two main steps, SOARES DE CARVALHO et al. 2006) that extends inland for more than $1500 \mathrm{~m}$, roughly parallel to the coastline.

The present coast is of mixed energy, wave and tide dominated. Tides are mesotidal, semi- diurnal, with mean amplitude of $1 \mathrm{~m}$ in neap tides and $2.8 \mathrm{~m}$ in spring tides. Maximum amplitude can reach $3.9 \mathrm{~m}$. Waves are characterized by mean height of $2 \mathrm{~m}$ and period of $9 \mathrm{~s}$. The main approach direction is from NW.

The platform presents two Palaeozoic formations (one from the Ordovician and another from the Silurian), crossed by quartz veins (TEIXEIRA et al. 1969; PEREIRA 1992). Structurally, the two formations constitute a syncline with a NW-SE axis. Its eastern flank is in contact with granites through faults and shear zones that are also orientated NW-SE. The Ordovician rocks of the western flank constitute the bedrock of the beaches.

This bedrock, forming a shore platform of c. $0.3^{\circ}$, outcrops on the beach. It presents morphological features that point to relative sea level changes during the last thousands of years. Many grooves of sea urchins (at a height of 0.0 to $1.0 \mathrm{~m}$ MSL) point to the existence of an infra-littoral environment while saltpans (at a height of -1.0 to $2.0 \mathrm{~m} \mathrm{MSL}$ ) to a supra-tidal environment (Fig. 2). A rusty conglomerate composed by well-rounded quartzite pebbles (conglomerate A) is also noticeable in some places overlaying the platform (Fig. 3).

The Pleistocene-Holocene sediments were accumulated in depressed areas of the platform, structurally controlled by fault strikes that cross the synclinal structure (NW-SE, NE-SW and E-W). Some of these faults were reactivated during Pleistocene-Holocene times (CABRAL 1993).

The Holocene coast would have been jagged, with headlands and small lagoons in between, protected by barriers located westwards of the present coastline. This is supported by the age and facies of the sedimentary deposits (Fig. 4) overlaying the platform and outcropping in the low tide area of present beaches along the NW Portuguese coastline (e.g. GRANJA 1999; SOARES DE CARVALHO \& GRANJA 2003; GRANJA et al. 2010; RIBEIRO et al. 2011).
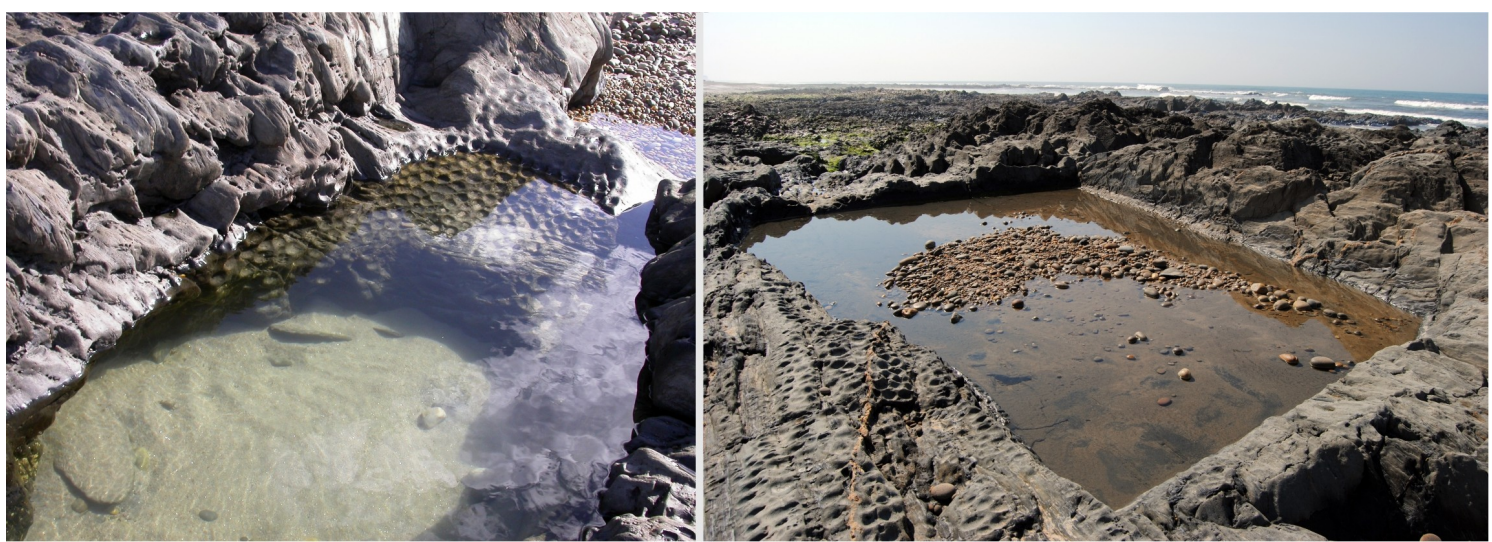

Fig. 2. Urchin casts (left) and saltpan (right) carved in the platform outcropping at Rio de Moinhos beach.

Fig. 2. Marcas de ouriços (à esquerda) e salina entalhada (à direita) na plataforma aflorante na praia de Rio de Moinhos. 


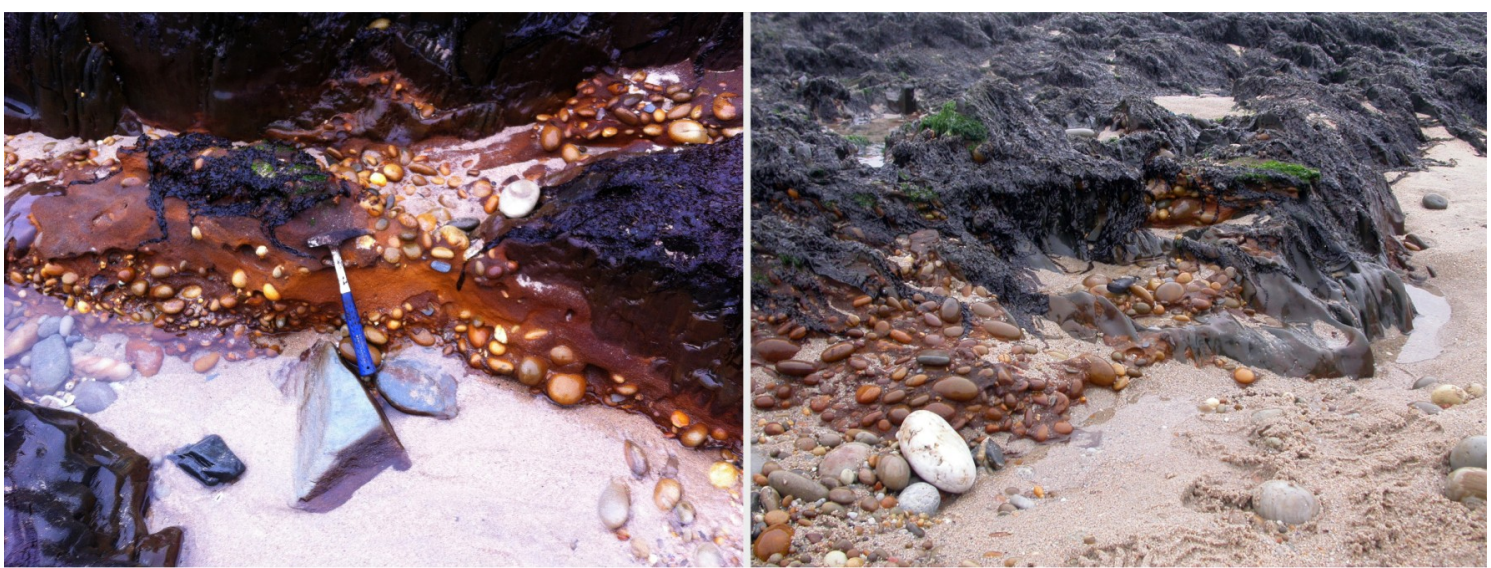

Fig. 3. Rusty conglomerate (conglomerate A) overlying the platform.

Fig. 3. Conglomerado ferruginoso (conglomerado A) assente na plataforma.

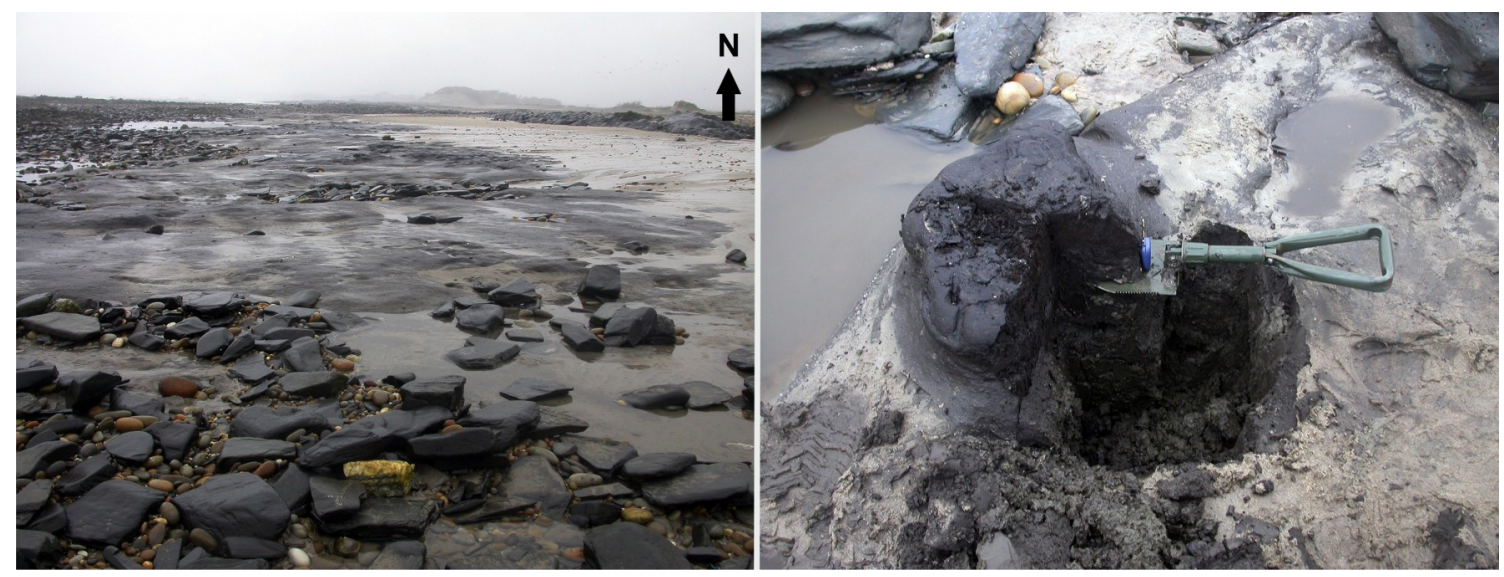

Fig. 4. Fine, dark and organic sedimentary deposit outcropping in the beach of Rio de Moinhos. General view (left) and detail (right).

Fig. 4. Afloramento do depósito fino, negro e orgânico da praia de Rio de Moinhos. Vista geral (esquerda) e pormenor (direita).

\section{METHODOLOGIES}

\section{Cores}

Several short cores were obtained from the sedimentary deposit outcropping in the low tide area of the beach (Fig. 1). Though variable, the sediment thickness over the platform is never higher than $50 \mathrm{~cm}$, so a hand gouge auger (with 2 $\mathrm{cm}$ internal diameter) was used.

The cores were opened and the main sedimentary facies identified. According to the facies, samples from each core section were taken for sedimentological analyses, pollen and diatom (not used in this paper) content, and dating. For this work ST8, ST10, ST13 were used for sedimentary analysis and ST1 for pollen identification. ST1 and ST2 were used for dating purposes.

\section{Sedimentary analysis}

Sedimentological analyses comprised the main composition, the size analyses, the organic matter content and the grain observation at a binocular magnifying glass.

Samples were dried at $40^{\circ} \mathrm{C}$ and weighed; then treated with $\mathrm{H}_{2} \mathrm{O}_{2}$ to remove the organic matter, and again washed, dried and weighed. After this treatment, samples were ready to be separated by size fractions.

Grain size analysis was performed with a combination of dry sieving $(>63 \mu \mathrm{m})$ and Sedigraph $(<63 \mu \mathrm{m})$. Samples $<63 \mu \mathrm{m}$ were pre-treated with $\mathrm{Na}_{16} \mathrm{P}_{14} \mathrm{O}_{43}$ at $10 \%$ for deflocculation. After washing and drying, a solution was prepared for the analysis in the Sedigraph.

The laboratory routines were done according to TUCKER (1988) and GALOPIM DE CARVALHO (2005). Statistical parameters were determined using Sedmac (HENRIQUES 2004) software.

\section{Pollen content}

From each sample, $1 \mathrm{~cm}^{3}$ was extracted, filtered with a sieve $(250 \mu \mathrm{m})$ and treated chemically according to standard procedures (FÆGRI \& IVERSEN 1975), including cold HF treatment for 48 hours in order to destroy everything except pollen and other palynomorphs.

Pollen and non-pollen palynomorphs (NPP) were then counted with the help of an optical mi- 
croscope at $600-1000 \mathrm{X}$ and identification was facilitated by a reference collection and pollen atlases. The pollen diagram was constructed using the Tilia and Tilia graph (GRIMM 1991-93).

\section{Radiocarbon dating}

Organic sediments and wood were radiocarbon dated by specialized laboratories (Table 1). Organic sediments were dated by AMS. The cali- bration of the dates was performed with Calib 7.0.4 (STUIVER \& REIMER 1993) program, using the IntCal13 calibration curve (REIMER et al. 2013).

The isotopic ratio ${ }^{13} \mathrm{C}$ was also assessed as it can give additional information about the marine and/or terrestrial origin of the organic matter (marine environments are enriched in ${ }^{13} \mathrm{C}$ compared with terrestrial ones).

\begin{tabular}{|c|c|c|c|c|c|c|c|c|}
\hline Core & Sample & Lab. Ref. & Material & $\begin{array}{c}\text { Depth } \\
\mathrm{cm}\end{array}$ & $\begin{array}{c}{ }^{14} \mathrm{C} \mathrm{BP} \\
\text { conventional }\end{array}$ & $\delta^{13} \mathrm{C}$ & $\begin{array}{c}\text { Cal BP } \\
2 \sigma \\
\end{array}$ & $\begin{array}{c}\text { Cal BC/AD } \\
2 \sigma \\
\end{array}$ \\
\hline - & RM-estaca & Sac-2973 & wood & surface & $1960 \pm 60$ & -25.0 & $\begin{array}{l}1737-1765(0,023357) \\
1770-2055(0,976643)\end{array}$ & $\begin{array}{l}106-180 \mathrm{AD}(0,976643) \\
185-213 \mathrm{AD}(0,023357)\end{array}$ \\
\hline ST1 & ST1.Ell & Beta-373413 & $\begin{array}{l}\text { organic } \\
\text { sediment }\end{array}$ & $1-2$ & $3550 \pm 30$ & -27.1 & $\begin{array}{l}3721-3800(0,281657) \\
3811-3923(0,713697) \\
3953-3956(0,004646)\end{array}$ & $\begin{array}{l}2007-2004(0,004646) \\
1974-1862(0,713697) \\
1851-1772(0,281657)\end{array}$ \\
\hline ST1 & ST1.EXI & Beta-373414 & $\begin{array}{l}\text { organic } \\
\text { sediment }\end{array}$ & $17-20$ & $4060 \pm 30$ & -27.8 & $\begin{array}{l}4432-4626(0,922001) \\
4763-4788(0,077999)\end{array}$ & $\begin{array}{l}2839-2814(0,077999) \\
2677-2483(0,922001)\end{array}$ \\
\hline - & $\begin{array}{l}\text { Foz do } \\
\text { Neiva }\end{array}$ & SAC-2801 & Peat & surface & $4250 \pm 50$ & $-29,5$ & $\begin{array}{l}4590-4590(0,000559) \\
4615-4766(0,428813) \\
4784-4891(0,540950) \\
4902-4907(0,003472) \\
4927-4959(0,026207)\end{array}$ & $\begin{array}{l}3010-2978(0,026207) \\
2958-2953(0,003472) \\
2942-2835(0,540950) \\
2817-2666(0,428813) \\
2641-2641(0,000559)\end{array}$ \\
\hline - & ES. $85 \mathrm{M}$ & GX-31885 & wood & surface & $4570 \pm 80$ & -27.8 & $\begin{array}{l}4973-5021(0,038685) \\
5027-5471(0,952912) \\
5555-5571(0,008403) \\
\end{array}$ & $\begin{array}{l}3622-3606(0,008403) \\
3522-3078(0,952912) \\
3072-3024(0,038685)\end{array}$ \\
\hline - & RM.Lith & 16P/0310 & Peat & $\begin{array}{c}\text { surface } \\
(20 \mathrm{~cm} \text { above } \\
\text { bedrock) }\end{array}$ & $4680 \pm 30$ & -25.0 & $\begin{array}{l}5472-5319(0,953896) \\
5571-5554(0,046104)\end{array}$ & $\begin{array}{l}3622-3605(0,046104) \\
3523-3370(0,953896)\end{array}$ \\
\hline ST2 & ST2 & Beta-343355 & $\begin{array}{c}\text { organic } \\
\text { sediment }\end{array}$ & 30 & $4750 \pm 30$ & -27.1 & $\begin{array}{l}5331-5374(0,132416) \\
5459-5585(0,867584)\end{array}$ & $\begin{array}{l}3636-3510(0,867584) \\
3425-3382(0,132416)\end{array}$ \\
\hline ST1 & ST1.EXVII & Beta-373415 & $\begin{array}{l}\text { organic } \\
\text { sediment }\end{array}$ & $31-32$ & $4860 \pm 30$ & -28.2 & $\begin{array}{l}5488-5504(0,054373) \\
5582-5652(0,945627)\end{array}$ & $\begin{array}{r}3703-3633(0,945627) \\
3555-3539(0,054373)\end{array}$ \\
\hline - & $\begin{array}{c}\text { PRP ESTE } \\
12\end{array}$ & Beta-336535 & wood & $\begin{array}{c}\text { under } \\
\text { beachsand }\end{array}$ & $5480 \pm 30$ & -32.8 & $\begin{array}{l}6209-6254(0,257549) \\
6258-6318(0,740245) \\
6379-6382(0,002206)\end{array}$ & $\begin{array}{l}4433-4430(0,002206) \\
4369-4309(0,740245) \\
4305-4260(0,257549)\end{array}$ \\
\hline - & ES.85 T & GX-31886 & wood & surface & $5590 \pm 80$ & -29.6 & $\begin{array}{l}6214-6243(0,020542) \\
6268-6563(0,979458)\end{array}$ & $\begin{array}{l}4614-4319(0,979458) \\
4294-4265(0,020542)\end{array}$ \\
\hline - & - & - & peat & surface & $5880 \pm 60^{*}$ & - & $\begin{array}{l}6533-6808(0,947044) \\
6811-6857(0,052327) \\
6875-6876(0,000629)\end{array}$ & $\begin{array}{l}4927-4926(0,000629) \\
4908-4862(0,052327) \\
4859-4584(0,947044)\end{array}$ \\
\hline
\end{tabular}

CALIB RADIOCARBON CALIBRATION PROGRAM (7.0.4). Copyright 1986-2016 M Stuiver and PJ Reimer. Stuiver, M., and Reimer,

P.J., 1993, Radiocarbon 35, 215-230.

Reimer et al. 2013. IntCal13 and MARINE13 radiocarbon age calibration curves 0-50000 years calBP, Radiocarbon 55 (4). DOI: 10.2458/azu_js_rc.55.16947

${ }^{*}$ Ribeiro et al. 2011

\section{Lithic artefacts}

The lithic artefacts have been collected from the surface of the deposits outcropping at the beach of Rio de Moinhos since surveys started in 2012 (Fig. 1). As the access to the archaeological layers was possible only during low tide, the collection procedures were very expeditious. Basically, only the stratigraphic and the spatial context of the artefacts were recorded (mainly through photography). Although no excavations were done it is possible, at the moment, to determine the exact stratigraphic position of the artefacts.

The description and the analysis of the lithic assemblages (MONTEIRO-RODRIGUES 2013) were based on criteria developed by several authors who have been studying macrolithic industries from different regions of Portugal (e.g. MEIRELES 1992, CUNHA-RIBEIRO 1999, MONTEIRO-RODRIGUES 1996). Specifically, the classification of the cores followed Santonja (1984-85). The analysis of the pebbles with only one distal removal, which are related to bipolar knapping on anvil, was based on Mourre (1996, 2004) and Prous et al. (2009-2010). The thermoclasts study followed the work of Leesch (1997) and Sampaio (2009). The analysis of the lithic artefacts from Rio de Moinhos beach also included some experimental procedures described in MonteiroRodrigues (2013). 


\section{RESULTS}

\section{Sedimentary facies characterization}

The exposed rocky platform is clean or overlaid by a thin sedimentary deposit. The platform itself is polished and presents many casts of sea urchins (infra-littoral environment) at heights between 0.0 and $2.0 \mathrm{~m} \mathrm{MSL}$, as well as saltpans (supratidal environment) at heights between -1.0 and $2.0 \mathrm{~m}$ MSL, both of uncertain age (Fig. 2).

A deposit of cemented and rusty rounded quartzite pebbles forming a conglomerate (conglomerate A), overlying the platform, outcrops in some low tide areas of the beach (Fig. 3).
Looking at the short cores ST, some variation in their main composition (relative \% of gravel, sand, silt and clay) can be observed. However, two main units can be considered: the lower, coarser, with $>50 \%$ of sand and gravel (U I), and the upper, finer, with $>50 \%$ of silt and clay (U II) (Fig. 5A). The fining upwards is in accordance with the increase of organic matter, very high in the topmost layers.

ST13, as a whole, is coarser and more homogeneous than ST8 and ST10.

Looking at Folk and Ward statistics (Fig. $5 \mathrm{~B}$ ), all the sediments from the cores present high values of standard deviation which means very

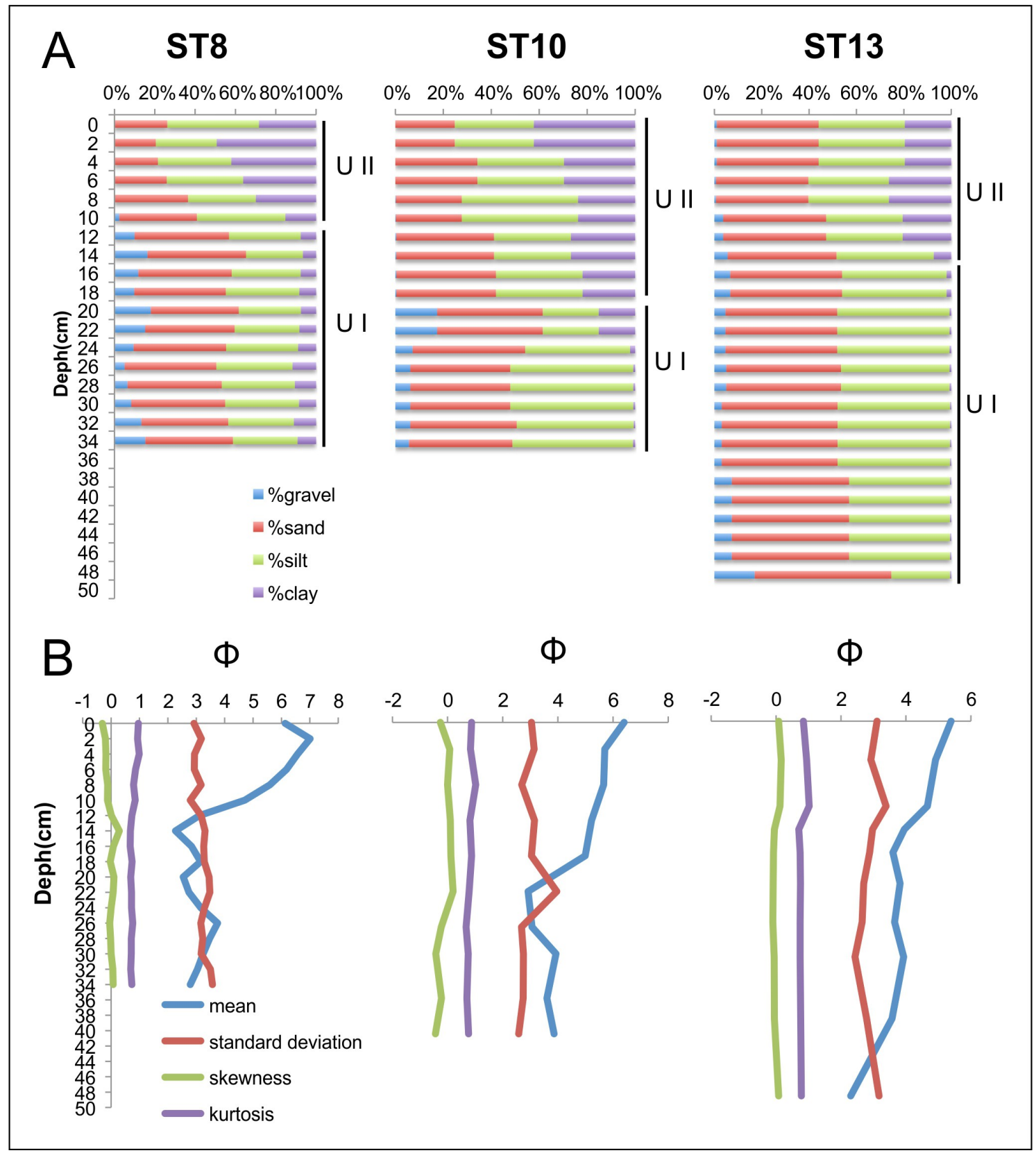

Fig. 5. Sedimentary main composition (A) and Folk and Ward statistics (B) of ST cores.

Fig. 5. Composição sedimentar principal (A) e estatísticos de Folk e Ward (B) dos cores ST. 
poorly sorted sediments. On closer inspection, U I can be sub-divided in two fining and two coarsening upwards alternating sets, more evident in ST8 and ST10 and less perceptible in ST13, that is, as a whole, coarser than the others. This means that some spatial heterogeneity related with the dynamics and sedimentary inputs was present which is not incompatible with a wet area environment. The unit U II is fining upwards except in the uppermost $2 \mathrm{~cm}$ of ST8.

Fining upwards and increasing organic content is compatible with a quiet water environment where deposition is slow and biological activity is favoured.

The samples observed with the binocular magnifying glass show very immature quartz grains, with sharp edges, which points to proximal sources and small transport, and hence, terrigenous genesis.

\section{Palynology}

Tree stumps and roots of Alnus glutinosa aged 5590 \pm 80 yr BP (4614-4319 cal BC $2 \sigma)$ and

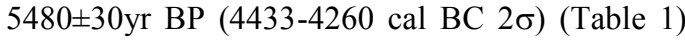
are found at the base of the sedimentary sequence.

The pollen diagram (Fig. 6) may be divided into three pollen assemblage zones (PAZ) mainly on the basis of changes in local pollen assemblages (GRANJA \& DANIELSEN 2015). Regional vegetation seems to have been a relatively permanent oak forest.

From the base to the top of the sequence, the three PAZ are as follows:

\section{PAZ I (34-31 cm): Wetland}

Local vegetation is dominated by aquatic or semi-aquatic quillworts (Isoetes) together with Poaceae and Cyperaceae. Other well represented hygrophilous herbs were Potamogeton, Hydrocotyle and Lythrum salicaria. Alnus and Salix were common in the local wetland while in the drier upland vegetation the predominant trees were various oaks (Quercus). Hedera helix is present with high percentages and seems to have grown locally at this stage. The content of large pollen of Poaceae (possibly Cerealia) may indicate agriculture and human presence in the vicinity of the wetland in this more ancient deposit although we cannot discard the inflection of Cerealia type produced by salt marsh and dune Poaceae (MATEus 1992).

This phase ends at $4860 \pm 30$ yr BP (37033539 cal BC $2 \sigma)$. wetland

PAZ II (31-18.5cm): Brackish influenced

This environment encompasses the interval between $4860 \pm 30 \mathrm{yr}$ BP (3703-3539 cal BC $2 \sigma)$ and $4060 \pm 30 \mathrm{yr}$ BP $(2839-2483 \mathrm{cal} \mathrm{BC} 2 \sigma)$.

The pollen assemblage is typical of a lagoon or wetland influenced by brackish water creating eutrophic conditions. The site was characterized by Alnus and Salix during this period, typical genera of eutrophic lagoon edge forests. Hygrophilous shrubs and herbs dominate the local pollen assemblage. Myrica has high representation and various Cyperaceae species have peak appearances. Ferns of the Polypodiaceae family seem to have been common at this stage.

The upland vegetation remains relatively stable and characterized by oak forest. One pollen grain of Hordeum was identified at this stage and, together with the marked increase of ruderal plants from Brassicaceae and Papaveraceae, may indicate agricultural practices in the near vicinity. Noticeable for this zone is, furthermore, the high content of charcoal particles with peak values in the darker layer. The arboreal pollen content, be it local or regional, does not show large changes at this level. The local edge forest of Alnus and Salix only disappeared some time after the charcoal peak. The Poaceae curve, however, is inversely correlated to the charcoal curve at this stage. This may possibly be an indication of deliberate burning of the fields by the local population. Charcoal particles may also have originated from fireplaces or hearths.

\section{PAZ III (18.5-0cm): Fresh water lake}

This environment occurred between $4060 \pm 30$ yr BP (2839-2483 cal BC $2 \sigma)$ and $3550 \pm 30 \mathrm{yr}$ BP (2007-1772 cal BC 2 $\sigma$ ).

During this period the site was inundated by fresh water and aquatic plants became abundant. Nymphaea, Myriophyllum alterniflorum and Sparganium were the most common, and fresh water algae appeared represented by Botryococcus and Pediastrum boryanum. Presence of aquatic plants and the green algae Pediastrum, in particular, are proof of the exclusion of salt water in this period as they are not salt tolerant (MEDEANIC 2006). The edge forest disappeared or receded to dryer areas and pollen from Alnus and Salix strongly decrease.

The upland vegetation remains relatively constant and does not seem to have been influenced by the inundation of the local site. Relatively high values of Chenopodiaceae pollen may reflect the establishment of saltmarshes in the area bordering the lake towards the ocean. During this phase we find possible indications of pastures due to the increased presence of species of the Plantaginaceae (BEHRE 1981) and scattered occurrence of pollen of Urtica.

\section{Dating}

At the moment eleven ${ }^{14} \mathrm{C}$ datings are available for the sedimentary deposit from Rio de Moinhos beach: four were obtained from organic sediment, four from wood and three from peat (Table 1). 

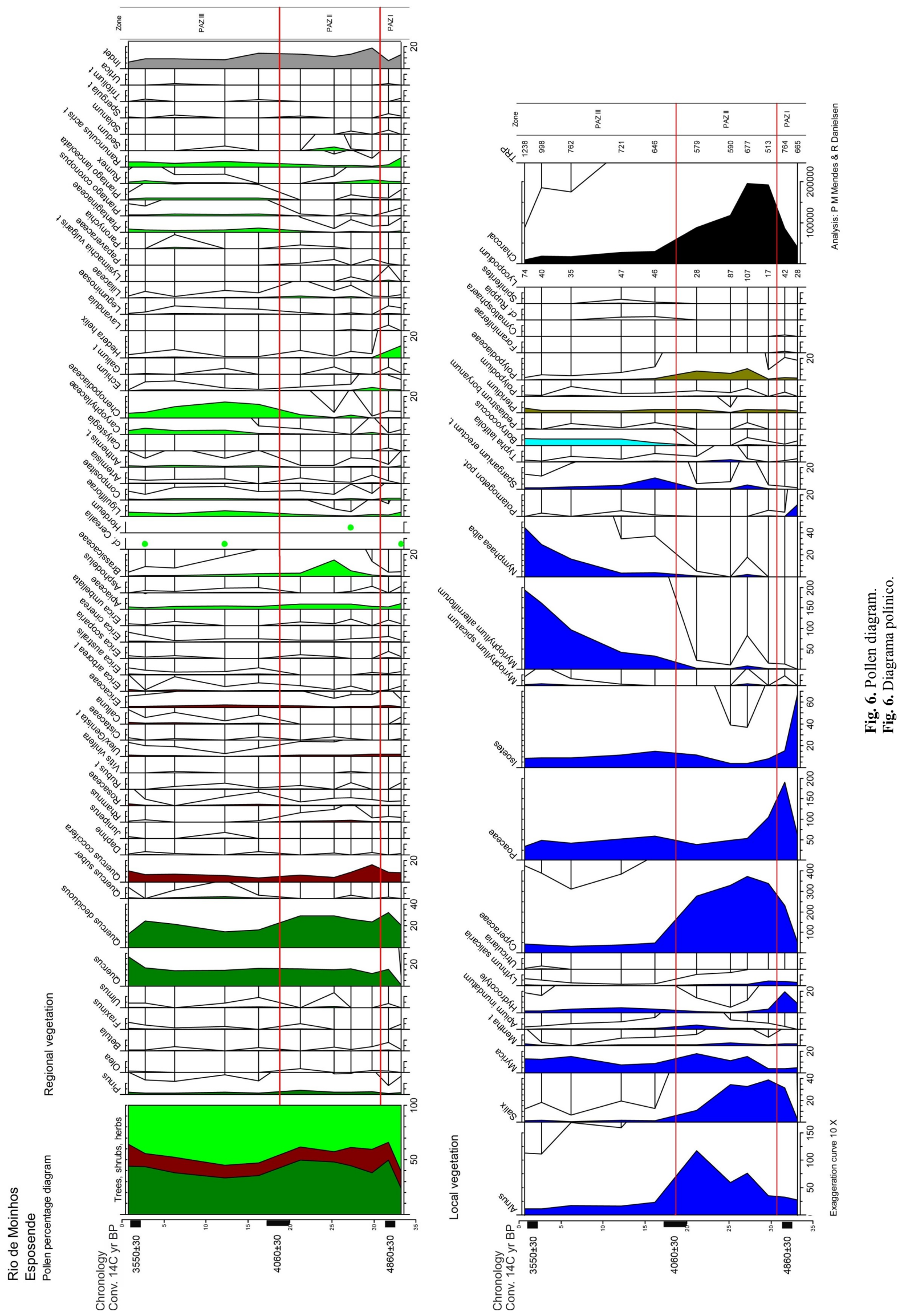
Tree stumps of Alnus glutinosa in life position gave the age of $5590 \pm 80 \mathrm{yr} \mathrm{BP}(4614-4319 \mathrm{cal} \mathrm{BC}$ $2 \sigma)$ and $5480 \pm 30$ yr BP $(4433-4260$ cal BC $2 \sigma)$, and a wood fragment, apparently an artefact (?), was dated to $4570 \pm 80 \mathrm{yr}$ BP (3622-3024 cal BC $2 \sigma$ ).

The stumps are prior to the basal level of the dark and fine sedimentary sequence, corresponding to PAZ I, whose top is of the age $4860 \pm 30 \mathrm{yr}$ BP (3703-3539 cal BC 2 $\sigma$ ). Alnus was common in PAZ I and PAZ II (a progressively brackish wetland). The woody artefact may be contemporary to PAZ II which ends around $4060 \pm 30$ yr BP (2839$2483 \mathrm{cal} \mathrm{BC} 2 \sigma$ ). At this level there is a noticeable abundance of charcoal which may be a consequence of wild fires or deliberate burning by man.

PAZ III (fresh water lake) ends abruptly at $3550 \pm 30$ yr BP (2007-1772 cal BC $2 \sigma)$ with a strong decrease of Alnus.

Stratigraphic position and techno-typological characteristics of the lithic industry

Field observations allowed the recognition of two distinct artefactual sets (Fig. 7): i) a very rolled one (represented by 48 units) and ii) a non-rolled one (represented by 446 units) (MONTEIRORODRIGUES 2013) $)^{1}$.

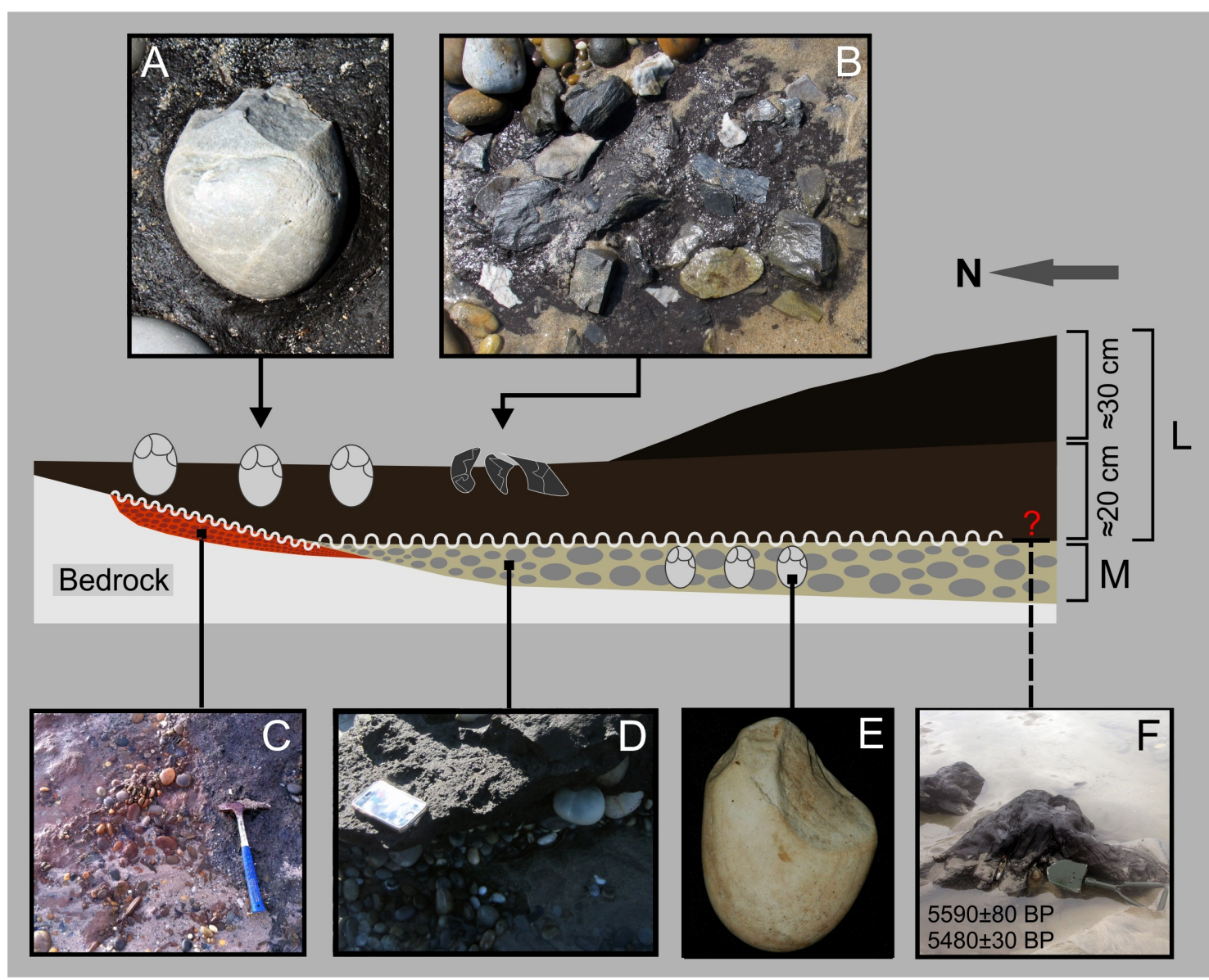

Fig. 7. The stratigraphic position of the lithic artefacts from Rio de Moinhos beach. L) Lagoon deposit. M) Marine conglomerate (conglomerate B). A) Chopper in situ in the base of the lagoon sediment. B) Fire-cracked pebbles in situ in the base of the lagoon deposit. C) Rusty conglomerate over the bedrock (conglomerate A). D) Conglomerate underlying the lagoon deposit (conglomerate B). E) Rolled chopper from conglomerate B. F) Tree stumps in life position apparently overlying the marine deposits and underlying the lagoon sediments dated to $5590 \pm 80 \mathrm{yr} \mathrm{BP}(4614-4319 \mathrm{cal} \mathrm{BC} 2 \sigma)$ and $5480 \pm 30 \mathrm{yr}$ BP (4433-4260 cal BC $2 \sigma)$.

Fig. 7. Contexto estratigráfico dos artefactos líticos da praia de Rio de Moinhos. L) Depósito lagunar. M) Conglomerado marinho (conglomerado B). A) Seixo talhado unifacial in situ na base do sedimento lagunar. B) Termoclastos in situ na base do depósito lagunar. C). Conglomerado ferruginoso sobre o bedrock (conglomerado A). D) Conglomerado sob o depósito lagunar (conglomerado B). E) Seixo talhado unifacial rolado do conglomerado B. F) Troncos de árvore em posição de vida, aparentemente sobre os depósitos marinhos e sob os sedimentos lagunares datados de 5590 \pm 80 yr BP (4614-4319 cal BC $2 \sigma)$ e $5480 \pm 30$ yr BP (4433-4260 cal BC $2 \sigma)$. 
The first set was associated with a conglomeratic to sandy deposit (conglomerate B, Fig. 7D) that underlies the lagoon sediments and overlies the bedrock and, apparently, the rusty conglomerate (conglomerate A, Fig. 7C). A few rolled artefacts also occur in the lowest $20 \mathrm{~cm}$ of the dark sequence, which roughly corresponds to PAZ I and PAZ II.

The other set - the non-rolled one - was identified exclusively in the lowest $20 \mathrm{~cm}$ thick level of the dark deposit; the top of this level was dated to $4680 \pm 30 \mathrm{yr}$ BP $(3622-3370$ cal BC $2 \sigma)$, thus representing the terminus ante quem for this lithic assemblage. As mentioned above, the absence of traces of rolling in the stone-tools of this set, the existence of refittings among the artefacts (Fig. 8) and the thermoclasts, and the occurrence of small size flakes suggest that this assemblage may be in situ (MONTEIRO-Rodrigues 2013). At the north end of the outcrop, where the sedimentary sequence is thinner, these artefacts occur almost in contact with the bedrock or occasionally over the rusty conglomerate A (Fig. 7C).
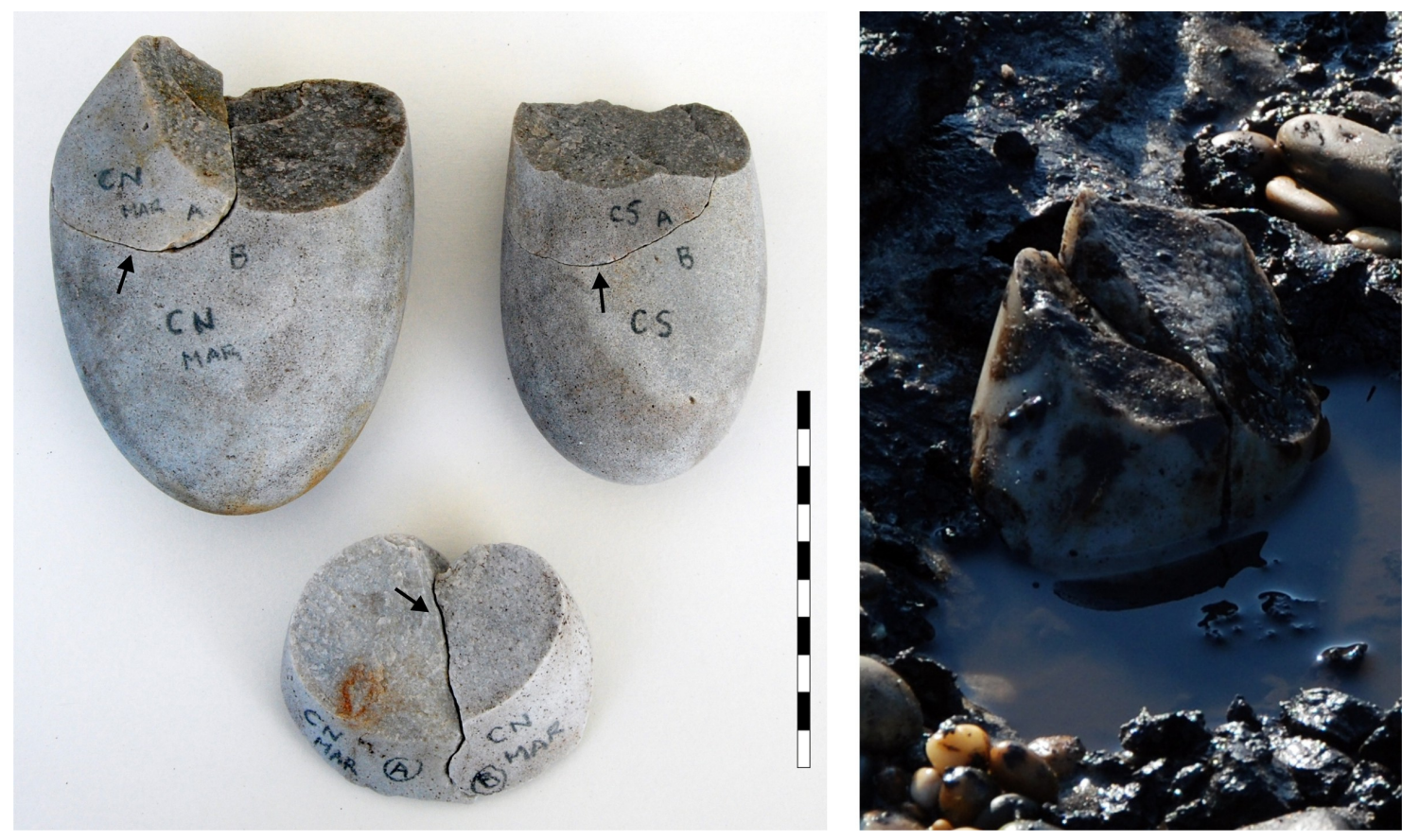

Fig. 8. Refittings from the base of the lagoon deposit

Fig. 8. Remontagens identificadas na base do depósito lagunar.

In the southern and eastern sectors of the outcrop, where the sedimentary sequence is thicker, no lithic artefacts were found at the surface. This suggests that the artefacts are in fact related to the lowest levels of the lagoon deposit.

As some of the rolled artefacts show nonrolled negatives (i.e. double patina) it is assumed that the rolled assemblage is older than the nonrolled one. On the other hand, the rolled assemblage includes "picks" (picos), a morphotype that is known in several Pleistocene contexts (MONTEIRORODRIGUES \& CUNHA-RIBEIRO 1991; MEIRELES 1992), namely in the "Ancorense" (MIS 3/MIS 2 according to MEIRELES 1992, 2009), but also in the Holocene (MONTEIRO-RODRIGUES 2013).

From a techno-typological point of view, the lithic assemblage from Rio de Moinhos beach (MONTEIRO-RODRIGUES 2013) consists of cores (70), flakes (165), knapped pebbles (choppers, chopping tools, and others) (160), "picks" (picos) (3), flake tools (12), intentionally fractured pebbles
(55) and other atypical lithics (29). Almost all of these artefacts were made of local quartzite pebbles. The use of quartz is residual (c. $2 \%$ of the total).

In regard to the cores (Fig. 9), the most common are those of the group II $(>60 \%)$, followed by those of the group V $(>26 \%)$ (SANTONJA 198485). Among the latter, two distinct debitage sequences were identified (MONTEIRO-RODRIGUES 2013). A third technotype - cores with radial invasive removals, defined by Meireles (1992) - is also present. Cores of the group I and III (SANTONJA 1984-85) have little expression.

The flakes are mostly cortical (primary) with cortical butts. This confirms the relevance of unifacial knapping within the lithic industries from the Minho Littoral region (MEIRELES 1992, 2009).

Among the knapped pebbles, three categories were identified: choppers (57), chopping tools (4) and pebbles with only one distal removal (99). Some of the latter, with a large removal and use- 
wear traces, were considered to have the same function as the choppers. Other cases, involving mostly small size pebbles, seem to be the result of bipolar knapping on anvil (MOURRE 1996, 2004; PROUS et al. 2009-2010; MONTEIRO-RODRIGUES 2013). For now, the functionality of these pebbles is unknown.

With regard to the "picks" (picos), a quite uncommon stone tool, their morphological variability must be mentioned (MEIRELES 1992) as well as the fact that they are present in both the rolled and the non-rolled lithic assemblages from the Rio de Moinhos beach (Fig. 10). This fact suggests that their production may have occurred during a long period of time, i.e. from the Pleistocene (MEIRELES 1992, 2009) to the Holocene (MONTEIRO-RODRIGUES 2013).
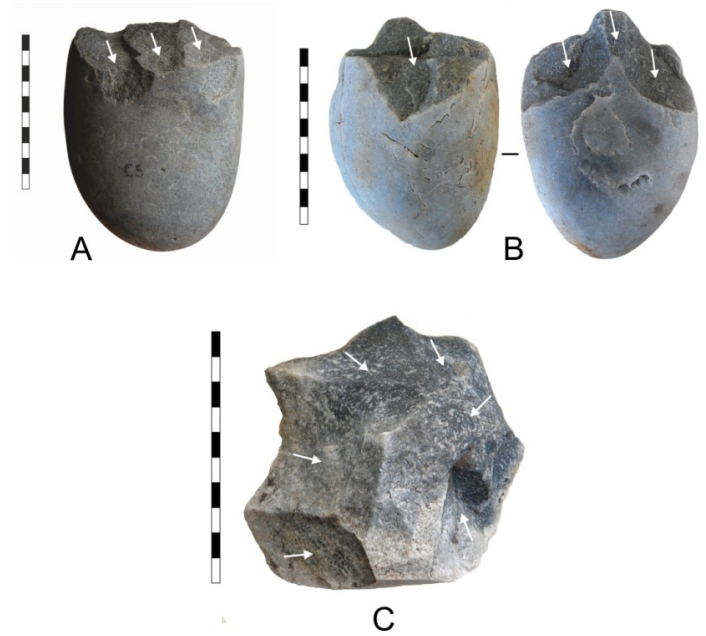

Fig. 9. A) Group II core. B) Group V core. C) Core with radial invasive removals.

Fig. 9. A) Núcleo do grupo II. B) Núcleo do grupo V. C) Núcleo de extracções radiais invasoras.

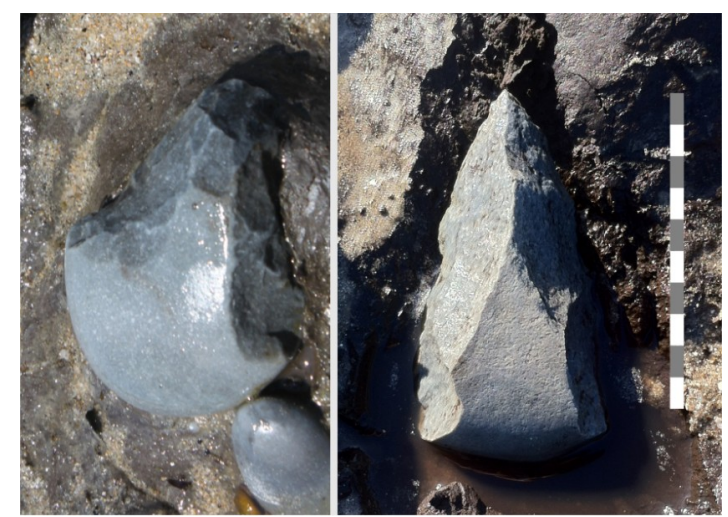

Fig. 10. "Picks" from the base of the lagoon deposit. A rolled one (left) and a non-rolled one (right).

Fig. 10. Picos provenientes da base do depósito lagunar. Exemplar rolado (esquerda) e exemplar não rolado (direita)
Flake tools are very scarce (9). Basically, only retouched flakes and scrapers were found.

A last category of lithics consists of pebbles that were intentionally broken, in most cases according to a plan that is perpendicular to the major axis of the pebble (MONTEIRO-RODRIGUES 2013). These artefacts, also found in some other sites of the region (MEIRELES 1992), were broken locally as they do not show any traces of rolling, and in some cases refitting was possible (MONTEIRORODRIGUES 2013).

An important number of thermoclasts was found together with the non-rolled lithic assemblage (Fig. 7B). Some show flat and/or convex fractures; others exhibit polygonal microcracks (LEESCH 1997; SAMPAIO 2009). A small set was refitted.

\section{DISCUSSION}

The rusty conglomerate A is very probably contemporaneous with a high relative sea level when the platform was exposed to wave action (much like what happens currently, during spring tides, after the recent sand loss and beach retreating). Pebbles may be reworked from previous fluvio/marine deposits, located at higher levels, and brought by river flow. Pebble and cobble deposits exist landwards, over the highest unit of the low platform and even over the high platform (SOARES DE CARVAlHo et al. 2006). Pebbles and cobbles can also come from submerged deposits (GRANJA \& FERREIRA 2006).

Without any kind of age indicator (e.g. datable bio-indicators), it is hard to establish the probable period of platform immersion by sea or if there was more than one event of immersion and emergence. The platform presents sea urchin casts but also saltpans (Roman?; oral information of Brochado de Almeida), indicating, respectively, infra-littoral and supra-tidal positions, sometimes coexisting at the same site (Fig. 1). Though their relative antiquity is unknown, it is more plausible to accept that the existence of an infra-littoral environment on the present beach is prior to the installation of saltpans, since urchin casts are not found at the bottom but on their borders (Fig. 2). So, this would mean that the site (present spring low tide area of the beach) was subject to relative sea level fluctuations from MIS 5e (if conglomerate $\mathrm{A}$ is accepted to be Eemian) up until historical times, whose forcing factors are still under research.

During the Last Glacial (MIS 3/MIS 4) the platform and shelf were emerged. It is possible that continental deposits, other than fluvial, established on it and older marine deposits exposed at the time acquired their reddish "varnish" characteristic (conglomerate A).

After the Last Glacial Maximum (during MIS 2) and with sea level rising, deposits on the inner 
shelf would have been mobilised and reworked. Some of them are still nourishing present beaches (GRANJA \& PinHo 2013).

Tree stumps of Alnus glutinosa aged $5590 \pm 80$ yr BP (4614-4319 cal BC $2 \sigma)$ and $5480 \pm 30$ yr BP (4433-4260 cal BC $2 \sigma$ ) are evidence that a forest was present in Rio de Moinhos beach before its conversion into fresh wetland. This forest probably extended westwards of the present coastline, across an area emerged at that time. Some of the first observable tree stumps (GARCÍA-AMORENA et al. 2007) are in infra-tidal position.

We cannot know for certain if the forest was developed over the basal marine unconsolidated conglomerate $\mathrm{B}$, apparently overlaying conglomerate $\mathrm{A}$. However, at the moment, the most logical hypothesis suggests that the forest is posterior to both basal marine deposits (considering conglomerate $\mathrm{A}$ as Eemian and conglomerate $\mathrm{B}$ as prior to $5590 \pm 80$ yr BP).

Part of the rolled lithic assemblage is associated with the unconsolidated conglomerate $\mathrm{B}$, thus documenting the earliest traces of human presence at the site. In fact, by accepting that the marine deposits are underlying the palaeo-forest, this assemblage must be older than $5590 \pm 80 \mathrm{yr}$ BP (4614

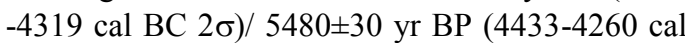
$\mathrm{BC}$ cal $2 \sigma$ ). As mentioned above, "picks" (picos) similar to those found in this assemblage have been related to different stages of the Pleistocene, namely with MIS 3/MIS 2, although they continue to be produced during the Holocene (MEIRELES 1992, 2009; MONTEIRO-RODRIGUES 2013). The forest of Alnus, over the unconsolidated gravel level, was inundated before $4860 \pm 30$ yr BP (3703-3539 cal BC $2 \sigma$ ), probably due to the rising sea level.

At Castelo do Neiva, north of Rio de Moinhos, a peaty outcrop on the beach was dated to $5880 \pm 60$ BP (4927-4584 cal BC $2 \sigma$ ) (RIBEIRO et al. 2011). According to these authors, this sediment corresponds to a rheotrophic hydrological regime where the water level always remained above the topographic surface of the basin, in a forest swamp. They also suggest that the environment was a wetland without marine influence, which is in accordance with the basal unit of Rio de Moinhos beach. According to its age $-5880 \pm 60$ yr BP (4927-4584 cal BC $2 \sigma)$ - this peaty layer (not yet found at Rio de Moinhos) could correspond to the organic level where the forest of Alnus was established.

At Foz do Neiva beach, non-rolled "picks" (picos) were found in a gravelly-sandy deposit under a lagoon sequence (peat from an outcrop of this sequence was dated to $4250 \pm 50 \mathrm{yr}$ BP $-3010-2641 \mathrm{cal}$ BC $2 \sigma-$ placing it within the temporal limits of PAZ II). This archaeological context needs, however, further research (MONTEIRO-RODRIGUES 2013).

The non-rolled assemblage occurs between the base of PAZ I - after $5590 \pm 80$ yr BP (46144319 cal BC $2 \sigma) / 5480 \pm 30$ yr BP (4433-4260 cal $\mathrm{BC} 2 \sigma$ ) - and a level dated to $4680 \pm 30 \mathrm{yr} \mathrm{BP}$ (3622-3370 cal BC $2 \sigma$ ), a few centimetres below the top of PAZ II $(4060 \pm 30 \mathrm{yr}$ BP, 2839-2483 cal $\mathrm{BC} 2 \sigma)$. This suggests that this lithic assemblage (that also includes "picks") was produced over a long period of time - roughly, from the end of the Early Neolithic to the Middle/Late Neolithic (c. $4600-4300 \mathrm{yr}$ BC to c. $3600-3400 \mathrm{yr}$ BC). However, one should not exclude the possibility that this assemblage relates to a shorter time range. In fact, the wide vertical distribution of the stone tools in the deposit may result from post-depositional processes (namely clay shrinkage). Despite this chronology, no pottery was found in the lagoon deposits.

The identification of fire-cracked pebbles among this lithic set confirms that human occupation occurred, at least sometimes, when the lagoon was dry. PAZ II - 4860 \pm 30 yr BP (3703-3539 cal BC $2 \sigma)$ to $4060 \pm 30 \mathrm{yr}$ BP $(2839-2483$ cal BC $2 \sigma)$ -, for example, shows a high content of charcoal which probably originated from hearths.

The presence of rolled artefacts in this organic deposit suggests sediment inputs from former deposits.

Regarding the livelihood activities of the prehistoric groups who visited Rio de Moinhos beach, almost no data is available. According to the palynological results, it is not possible to affirm that agriculture was practiced before $4860 \pm 30 \mathrm{yr}$ BP (3703-3539 cal BC $2 \sigma$ ). Although the identification of possible Cerealia based on large pollen size may be an indication of farming, a wild grass origin of these pollen grains is a more likely explanation.

However, after $4860 \pm 30$ yr BP (3703-3539 cal BC $2 \sigma$ ) and up until $4060 \pm 30$ yr BP (28392483 cal BC 2 $\sigma$ ) (PAZ II), agriculture, burning and anthropization is confirmed by the presence of pollen of Hordeum and weed plants together with the large peak in charcoal fragments.

During this interval (PAZ II) the water salinity increased slightly, the wetland becoming a brackish lagoon, presumably partially protected by a clastic barrier westwards.

The brackish lagoon transformed into a fresh water lake c. $4060 \pm 30 \mathrm{yr}$ BP (2839-2483 cal BC $2 \sigma)$. The lake seems to have existed at least until $3550 \pm 30 \mathrm{yr}$ BP (2007-1772 cal BC $2 \sigma)$, the date of the clearly truncated top sediment. This truncation can be related to marine flooding and overwashing as described by González-Villanueva et al. (2015) for the coastal wetlands of NW Iberia, following a phase of landward barrier retrogradation and aeolian sedimentation towards the back-barrier (not observable in Rio de Moinhos).

The sedimentary rates of lagoon infilling show an accentuated increase from PAZ I till PAZ III (Fig. 11). The rates are: for PAZ I 0.04 $\mathrm{mm} / \mathrm{yr}$, for PAZ II $0.17 \mathrm{~mm} / \mathrm{yr}$, and for PAZ III 


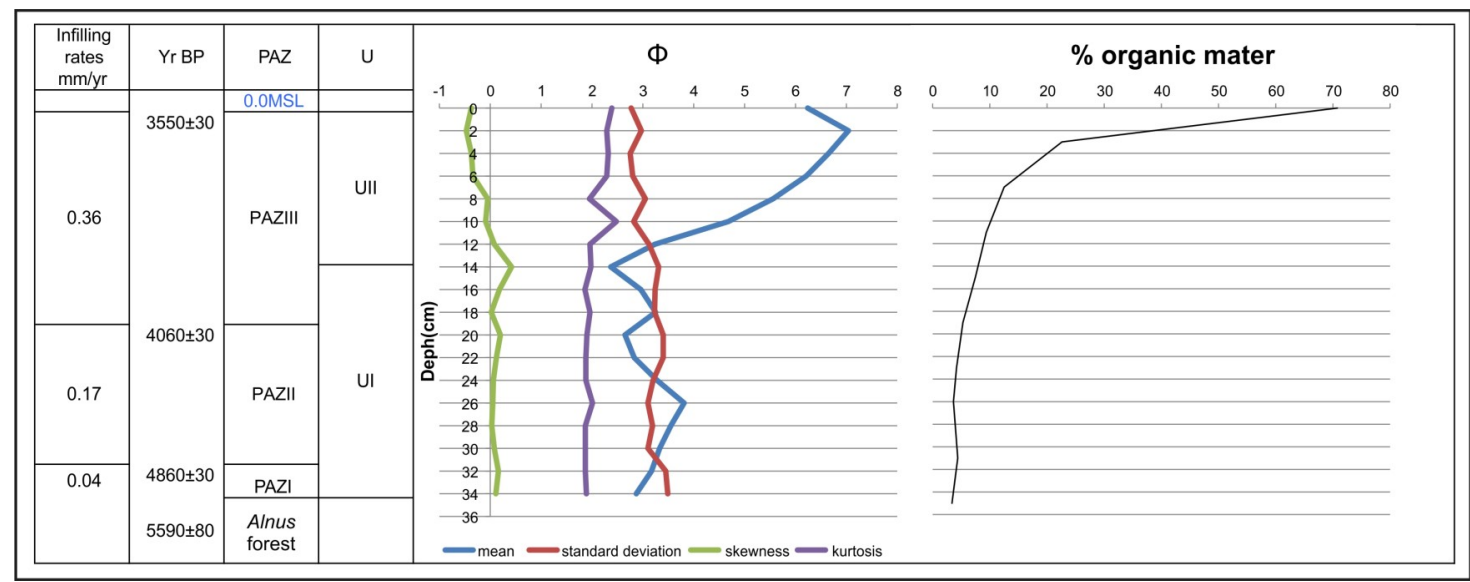

Fig. 11. Sedimentary and pollinic units, infilling rates and datings.

Fig. 11. Unidades sedimentares e polínicas, taxas de sedimentação e datações.

$0.36 \mathrm{~mm} / \mathrm{yr}$. Since the lagoon environment is essentially continental (quartz grains are very immature and marine indicators are nonexistent in the pollinic record), this increasing rate would mean that terrigenous inputs to the lagoon became more abundant along the time, especially after $4060 \pm 30$ yr BP (2839-2483 cal BC $2 \sigma)$. A contribution of very fine sediments characterises U II, the topmost layers of the sedimentary sequence, which are also the most organic.

This succession of environments (whose top is c. $0.0 \mathrm{~m} \mathrm{MSL}$ ) shows that after a slight salt water penetration, the environment changed to fresh water conditions and registered a silting-up increase, progressively finer and organic.

The increase of fresh water input in the area could be the result of a natural development caused by permanent closing of a clastic barrier westwards (due to an increase of sedimentary marine input) and/or a sea level rate change or, even, the increase of fluvial supply due to changes in precipitation. Leorri et al. (2012) state that values of sea level observations between 4000 and 2000 cal BP could represent a sea-level fall, though without any firm conclusion. If so, the increase of fresh water in the lagoon could be associated to such an event, or to a seaward shoreline migration without any significant sea level variation.

On the other hand, MUÑOZ SOBRINO et al. (2012) state that marine sedimentation reached its most ancient landward position before 4500 to $\mathrm{c}$. 3200 cal BP (in Ría de Vigo). This interval matches PAZ III, which would mean that marine influence, if any, was present during the former PAZ II brackish lagoon. However, the same authors also refer to short episodes of higher terrestrial influence between c. 4300-3800 and c. 3600-3200 cal BP. Although the second interval is missing in Rio de Moinho beach, the first corresponds to PAZ III (fresh water lake) which has the highest infilling rates, and its last phase (U II) consisting of the finest and most organic layers of terrigenous origin.
However, human interference cannot be excluded as anthropic activity was detected in the pollen assemblages since the formation of the lagoon. The age of mid PAZ III is close to Bond event 3 (4.2 Ky), responsible for worldwide aridification. Could people have built a dam to create a reservoir? Would agricultural practices have privileged erosion and could they have caused the silting-up increase of the lagoon during PAZ III? MARTINEZ-CORTIZAS et al. (2009) refer to a critical time of environmental disruption, with soil erosion, in NW Iberia, at 3.5-3.0 Ky. This could justify the high sedimentation rate in the lagoon from terrigenous origin, especially during the last phase (U II).

Shipwreck vestiges from the Roman Period (Augustus time), dispersed over the lake sediment (MORAIS et al. 2013), suggest that this coastal environment established a new communication with the sea somewhere after $3550 \pm 30$ yr BP (2007-

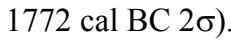

The age of the top level of the fresh water lake sequence may hence be the result of truncation due to erosion or eventually the consequence of manmade works in the lagoon. Furthermore, the presence of several aligned wooden stake remains, from Augustus time, buried in the lagoon sediment (GRANJA \& DANIELSEN 2015), as well as a kind of pavement made of large schist slabs (of unknown functionality), also highlight human action in the area.

\section{CONCLUSIONS}

Whatever the natural and/or anthropic forcing factors that were at work at Rio de Moinhos beach during the Mid-Holocene, the environment has changed through time successively as an Alnus forest, a wetland, a slightly brackish lagoon and, finally, a fresh water lake.

The increasing rate of lagoon infilling along time, indicating higher terrigenous inputs, can be related with human practices in the fluvial basin and/or climatic changes, such as those related with 
precipitation (that could have led to soil erosion and silt-clay inputs into the lagoon). The increasing rate of lagoon infilling is related with finer sediments pointing towards a passage to a very quiet environment (U II, PAZ III), where the organic content was very high - a eutrophic environment.

The earliest traces of human presence in Rio de Moinhos beach are documented by two lithic assemblages: a rolled one, of uncertain age - however, prior to $5590 \pm 80 \mathrm{BP}(4614-4319 \mathrm{cal} \mathrm{BC} 2 \sigma) /$ $5480 \pm 30$ BP (4433-4260 cal BC $2 \sigma)$, i.e. before the Alnus forest was developed - and a non-rolled one, apparently produced after $5590 \pm 80 \mathrm{BP} / 5480 \pm 30$ BP till $4680 \pm 30$ yr BP $(3622-3370$ cal BC $2 \sigma)$, i.e. after the inundation of the forest and before the fresh water lake was established.

Taking into account this chronological range, these artefacts may have been produced, roughly, sometime between the end of the Early Neolithic (second half of the $5^{\text {th }}$ millennium cal $\mathrm{BC}$ ) and the Middle/Late Neolithic (middle/second half of the $4^{\text {th }}$ millennium cal BC), and therefore may be related with some archaeological sites from these periods known in the Minho region (e.g. BETTENCOURT 2009, 2013).

The nature of the activities that were developed in the lagoon area is unknown. Assuming they were livelihood activities, they may have been some kind of complement to other activities such as agriculture and grazing, thus documenting the practice of a broad spectrum economy. If the macrolithic characteristics of the lithic industry are considered, it is possible to suggest that such activities did not require a great deal of precision. On the contrary, the artefactual package seems to be more suitable for cutting procedures, either by percussion (choppers and chopping-tools), or by back and forth movement (flakes and scrapers).

The palynological record shows cultivation of barley and increase in agricultural weed plants from around 3500 cal BC. Contemporaneous increase of charcoal particles show human activity through deliberate burning of fields and/or cooking on hearths from this point in time onwards.

Indications of grazing herds are found later in PAZ III from 4060 \pm 30 yr BP (2839-2483 cal BC 2 $\sigma)$, possibly partly explaining the increased erosion and high input of terrigenous sediment to the lake at the time.

\section{ACKNOWLEDGMENTS}

The sedimentological and palaeoecological data used in this paper is part of a FCT project on geo-archaeology (PTDC/EPH-ARQ/5204/2012), whose principal researcher is Professor Rui Morais. Authors are grateful to him for permission to use the data.

Authors want to acknowledge Ana Luísa Costa for her laboratorial work.

Sérgio Monteiro-Rodrigues is a researcher in $\mathrm{Co}$ Change project (HAR2014-51830-P), whose principal re- searcher is Pablo Arias, IIIPC, University of Cantabria.

This research was partially supported by the European Regional Development Fund (ERDF) through the COMPETE - Operational Competitiveness Programme and national funds through FCT - Foundation for Science and Technology, under the project Pest-C/ MAR/LA0015/2013.

\section{REFERENCES}

BEHRE, K.-E. 1981, The interpretation of anthropogenic indicators in pollen diagrams, Pollen et Spores 23: 225-245

Bettencourt, A.M.S. 2009. A Pré-história do Minho: do Neolítico à Idade do Bronze. In P. Pereira (coord.), Minho. Traços de Identidade. Braga: Universidade do Minho: 70-113.

Bettencourt, A.M.S. 2013. A Pré-história do Noroeste Português. Luiz Oosterbeek (Dir.) "Territórios da Pré-história em Portugal”, Vol. 2, Braga/Tomar (ARKEOS 36).

Bond, G.; ShOWERs, W.; CHESEBy, M.; LotTI, R.; Almasi, P.; deMenocal, P.; Priore, P.; Cullen, H.; HaJDAS, I. \& BONANI, G. 1997. A Pervasive Millennial-Scale Cycle in North Atlantic Holocene and Glacial Climates. Science 278 (5341): 1257-1266

CABral, J.M. 1993. Neotectónica de Portugal Continental. Lisboa: Universidade de Lisboa. (PhD thesis, not published).

Cunha-RiBeiro, J.P. 1999. O Acheulense no Centro de Portugal: o Vale do Lis. Contribuição para uma abordagem tecno-tipológicadas suas indústrias líticas e problemática do seu contexto cronoestratigráfico. 3 Vols. Lisboa: Faculdade de Letras da Universidade de Lisboa. (Phd thesis, not published).

FÆgri, K. \& IVERSEN, J. 1975. Textbook of Pollen Analysis. $3^{\text {rd }}$ Ed. Copenhagen: Scandinavian University Books.

García-Amorena, I.; Gómez Manzaneque, F.; RubiaLes, J.M.; Granja, H.; Soares de Carvalho, G. \& MorLA, C. 2007. The late Quaternary coastal forests of western Iberia: a study of their macroremains. Palaeogeography, Palaeoclimatology, Palaeocology 254: 448-461.

Galopim de Carvalho, A.M. 2005. Geologia Sedimentar. Sedimentologia, Vol. II. Colecção Sopas de Pedra, Lisboa: Âncora.

GonzÁlez-Villanueva, R.; Pérez-Arlucea, M.; Costas, S.; BAO, R.; Otero, X.L. \& GOBLE, R. 2015. 8000 years of environmental evolution of barrier-lagoon systems emplaced in coastal embayments (NW Iberia). The Holocene, Vol. 25, 11: 1786-1801.

GRANJA, H. 1990. Repensar a geodinâmica da zona costeira: o passado e o presente; que futuro? Braga: Universidade do Minho. (Phd Thesis, not published)

GranjA, H. 1999. Evidence for Late Pleistocene and Holocene sea level, neotectonic and climatic control in the coastal zone of Northwest Portugal. Geologie en Mijnbouw 77 (3-4): 233-245.

Granja, H. \& Ferreira, V. 2006. Geomorfologia da plataforma interna ao largo de Esposende (um caso de estudo - nota preliminar). Actas do $3^{\circ}$ Congresso Nacional de Geomorfologia, Funchal.

Granja, H. \& MoraIS, R. 2010. Diálogo entre ciências: 
estudo preliminar em torno dos estuários dos rios Cávado e Ave. In A.M.S. Bettencourt; M.I. Caetano Alves \& S. Monteiro-Rodrigues (eds.), Variações Paleoambientais e Evolução Antrópica no Quaternário do Ocidente Peninsular. Braga: APEQ/ CITCEM: 61-70.

Granja, H.; Rocha, F.; Matias, M.; Moura, R.; Caldas, F.; Marques, J. \& TAReco, H. 2010. Lagoa da Apúlia: a residual lagoon from Late Holocene (NW coastal zone of Portugal). Quaternary International 221: 46-57.

Granja, H.; Morais, R. \& FernándeZ, A. 2012. Was there a Roman shipwreck at Rio de Moinhos (Esposende, NW Portugal)? $4^{\text {th }}$ International Geologica Belgica Meeting 2012 (Brussels, 11-14 September), 1 p.

Granja, H. \& Danielsen, R. 2015. Atypical coastal environmental change during Copper Age-Bronze Age transition (Rio de Moinhos, NW Portugal) - Preliminary results. European Geosciences Union (EGU), Geophysical Research Abstracts, Vol. 17, 1 p.

Granja, H. \& PINHO, J.L. 2013. Gravel beaches: signals of changing. Proceedings of PAGES $2013-4^{\text {th }}$ Open Science Meeting (Goa, India): 103.

GRIMM, E.C. 1991-1993. TILIA and TILIA GRAPH. Springfield: Illinois State Museum.

HENRIQUES, R. 2004. SEDMAC/SEDPC: An application to support particle size analysis of unconsolidated sediments. 32 ${ }^{\text {nd }}$ International Geological Congress (Florence, Italy). Abstract book: 726.

LEESCH, D. 1997. Hauterive-Champréveyres, 10. Un campement magdalénien au bord du lac de Neuchâtel. cadre chronologique et culturel, mobilier et structure, analyse spatiale. Secteur 1. Neuchâtel: Musée Cantonal d'Archéologie (Archéologie neuchâteloise 19).

Leorri, E.; CeArreta, A. \& MiLne, G. 2012. Field observations and modelling of Holocene sea level changes in the Southern Bay of Biscay: implications for understanding rates of sea level change and vertical land motion along the Atlantic coast of SW Europe. Quaternary Science Reviews 42: 59-73.

Martinez-Cortizas, A; CostA-CAsais, M. \& LÓPEZSÁEZ, J.A. 2009. Environmental change in NW Iberia between 7000 and 500 cal BC. Quaternary International, Vol. 200, 1-2: 77-89.

MAteus, J.E. 1992. Holocene and present-day ecosystems of the Carvalhal region, Southwest Portugal. Utrecht: Utrecht University. (PhD Thesis).

MEDEANIC, S. 2006. Freshwater algal palynomorph records from Holocene deposits in the coastal plain of Rio Grande do Sul, Brazil. Review of Palaeobotany and Palynology 141: 83-101.

MeIreles, J. 1992. As Indústrias Liticas Pré-históricas do Litoral Minhoto. Contexto Cronoestratigráfico e Paleoambiental. Braga (Cadernos de Arqueologia 7, Monografias).

MeIRELeS, J. 2009. Os Primeiros Povoadores. A Pré-história Antiga do Minho. In P. Pereira (Coord.), Minho. Traços de Identidade, Braga: Universidade do Minho: 20-66.

MonteIRo-Rodrigues, S. 1996. Contribuição para o Estudo das Indústrias Liticas do Vale do Rio Caia (Alto Alentejo - Portugal). Porto: Faculdade de Letras do Porto. (Master thesis, not published).
MONTEIRO-RoDrigueS, S. 2013. A indústria macrolítica holocénica da Praia de Rio de Moinhos (Marinhas, Esposende, NW de Portugal). Apresentação de um estudo preliminar. Gallaecia 32: 87-108.

Monteiro-Rodrigues, S. \& CunHA-Ribeiro, J.P. 1991. A Estação Paleolítica do Cerro - Madalena, Vila Nova de Gaia. Revista da Faculdade de Letras da U.P. História, II série, Vol. VIII: 411-428.

Monteiro-Rodrigues, S.; Morais, R.; Granja, H.; DANiElsen, R.; Oliveira, C. \& BROChado DE AlmeIDA, C.A. 2013. Uma abordagem multidisciplinar ao sítio arqueológico da Praia de Rio de Moinhos - Esposende, NW de Portugal. In Alberto Gomes \& S. Monteiro-Rodrigues (Coords.), V Jornadas do Quaternário - $5^{\text {th }}$ International Conference - O Quaternário da Península Ibérica: Abordagens Metodológicas e Linhas de Investigação. Livro de Resumos/Pré-actas. Porto, APEQ: 44-45.

Morais, R.; Granja, H. \& Morillo CERdán, A. (eds.) 2013. O Irado Mar Atlântico. O naufrágio bético augustano de Esposende (Norte de Portugal). Braga: CECH, CIIMAR.

Mourre, V. 1996. Le débitage sur enclume au Paléolithique inférieur et moyen. Techniques, methods et schémas conceptuels. Nanterre. (Available on-line).

Mourre, V. 2004. Le débitage sur enclume au Paléolithique Moyen dans le Sud-Oest de la France. In P. van Peer, D. Bonjean \& P. Semal (eds.), Actes du XIV $V^{\text {ème }}$ Congrès de l'UISPP - Session 5: Paléolithique Moyen (Liége, 2-8 Sept. 2001), Oxford: 29-38.

MuÑoz Sobrino, C.; García-Gil, S.; Iglesias, J.; MartíneZ CARREÑo, N.; FERREIRO dA COSTA, J.; DÍAZ VARELA, R.A. \& JUDD, A. 2012. Environmental change in the Ría de Vigo, NW Iberia, since the mid-Holocene: new palaeoecological and seismic evidence. Boreas, Vol. 41-4: 578-601.

Oliveira, C.; Morais, R. \& ARAÚJO, A. 2015. Application of Gas Chromatography coupled with Mass Spectrometry to the analysis of ceramic containers of Roman Period. Evidence from the Peninsular Northwest. In César Oliveira, Rui Morais \& Ángel Morillo Cerdán, Archaeoanalytics. Chromatography and DNA analysis in Archaeology, Esposende: Município de Esposende: 193-212.

PereIRA, E. (CoORD.) 1992. Notícia Explicativa da Carta Geológica de Portugal na escala 1:200 000, Folha 1. Lisboa: Serviços Geológicos de Portugal.

Prous, A.; Alonso, M.; SouzA, G.N.; Lima, A.P. \& AMORELI, F. 2009-2010. La place et les caractéristiques du débitage sur enclume («bipolaire») dans les industries brésiliennes. Paleo, numéro spécial: 201-220.

ReIMER, P.J.; BARD, E.; BAYLISS, A.; BeCK, J.W.; BLACKWell, P.G.; RAMSEY, C.B.; BucK, C.E.; ChenG, H.; Edwards, R.L.; Friedrich, M.; GroOtes, P.M.; GuIlderson, T.P.; HAFlidason, H.; HAJDAS, I.; HatTÉ, C.; HeATON, T.J.; HofFMANN, D.L.; HogG, A.G.; Hughen, K.A.; KaISER, K.F.; Kromer, B.; MANNING, S.W.; NIU, M.; REIMER, R.W.; RICHARDS, D.A.; SCOTT, E.M.; SOUTHON, J.R.; STAFF, R.A.; TURNEY, C.S.M. \& VAN DER PLICHT, J. 2013. IntCal13 and Marine13 Radiocarbon Age Calibration Curves 0-50,000 Years cal BP. Radiocarbon 55 (4): 1869-1887. 
Ribeiro, H.; Bernal, A.; Flores, D.; Pissarra, J.; Abreu, I.; ROMANI, J.V. \& NORONHA, F. 2011. A multidisciplinary study of an organic-rich mudstone in the Middle Holocene on the Northern coast of Portugal. Comunicações Geológicas 98: 93-98.

SAMPAIO, J.D. 2009. Abordagem experimental aplicada ao estudo de estruturas pétreas gravettensesdo sítio de Olga Grande 4 (Vila Nova de Foz Côa). Porto: Faculdade de Letras da Universidade do Porto. (Master thesis, not published).

SANTONJA, M. 1984-85. Los núcleos de lascas en las industrias paleolíticas de la meseta española. Zephyrvs, Vol. XXXVII-XXXVIII: 17-33.

Soares de Carvalho, G. \& Granja, H. 2003. As mudanças da zona costeira pela interpretação dos sedimentos plistocénicos e holocénicos (a metodologia aplicada na zona costeira do NO de Portugal). Revista da Faculdade de Letras da Universidade do Porto-Geografia, I série, Vol. XIX: 225-236.
Soares de Carvalho, G.; Granja, H.M.; Loureiro, E. \& HenRiques, R. 2006. Late Pleistocene and Holocene environmental changes in the coastal zone of Northwestern Portugal. Journal of Quaternary Science, Vol. 21, 8: 859-877.

StUiver, M. \& ReimeR, P.J. 1993. A computer program for radiocarbon age calibration. Radiocarbon 35: 215230 .

Teixeira, C.; Medeiros, A.C.; Alves, C.A.M. \& MoreiRA, M.M. 1969. Carta Geológica de Portugal na Escala 1:50000. Notícia Explicativa da Folha 5-C Barcelos. Lisboa: Serviços Geológicos de Portugal.

TUCKER, M.E. 1988. Techniques in Sedimentology. Blackwell Scientific Publications. 